Article

\title{
Agricultural Productivity Growth and Its Determinants in South and Southeast Asian Countries
}

\author{
Jianxu Liu ${ }^{1,2}$, Mengjiao Wang ${ }^{2, *(\mathbb{D})}$, Li Yang ${ }^{1}$, Sanzidur Rahman ${ }^{1,3}{ }^{\mathbb{D}}$ and \\ Songsak Sriboonchitta ${ }^{2}$ \\ 1 Shandong University of Finance and Economics, Faculty of Economics, Jinan 250000, China; \\ liujianxu1984@163.com (J.L.); liyang@sdufe.edu.cn (L.Y.); srahman@plymouth.ac.uk (S.R.) \\ 2 Faculty of Economics, Chiang Mai University, Chiang Mai 50200, Thailand; songsakecon@gmail.com \\ 3 Plymouth Business School, University of Plymouth, Drake Circus, Plymouth PL4 8AA, UK \\ * Correspondence: mengjiaow1991@163.com
}

Received: 27 May 2020; Accepted: 16 June 2020; Published: 18 June 2020

check for updates

\begin{abstract}
Improving agricultural productivity is a priority concern in promoting the sustainable development of agriculture in developing countries. In this study, we first apply stochastic frontier analysis (SFA) to analyze the growth of agricultural total factor productivity (TFP) and its three components (technical change-TC, technical efficiency change-TEC and scale change-SC) in 15 south and southeast Asian countries covering the period 2002 to 2016 . Then, the determinants of agricultural TFP growth are identified using dynamic panel data models. The results reveal that the south and southeast Asian countries witnessed an overall decline in agricultural productivity during the sample period, thereby creating concerns over sustaining future agricultural growth. Technical progress was the major source of TFP growth, but its contribution has slowed in recent years. On the other hand, declining scale change and technical efficiency change resulted in the deterioration of productivity over time. Variable levels of productivity performances were observed for individual countries, mainly driven by technological progress. Overall, southeast Asia achieved a more stable and sustained agricultural growth as compared to south Asia. Among the determinants, human capital, level of urbanization, and development flow to agriculture positively influenced agricultural TFP growth, while the level of economic development and agricultural import were negatively associated with TFP growth. Policy recommendations include the suggestions that south and southeast Asian countries should increase investment in human capital, focus on technological innovation and make use of financial assistance and development flow to agriculture to increase and sustain agricultural productivity. In addition, frontier countries of the two regions (e.g., India and Indonesia) should take the lead on regional agricultural development ventures by enhancing cooperation with neighboring countries on technological innovations, and countries facing diseconomies of scale (i.e., Afghanistan and Iran) should consider the rational reallocation of agricultural inputs.
\end{abstract}

Keywords: stochastic frontier analysis; agricultural total factor productivity; scale change; technical change; technical efficiency change; south and southeast Asia

\section{Introduction}

The growth of global population and rising income are driving up global food demand. How to accelerate agricultural productivity on a sustainable basis to meet the increasing demand for food despite land degradation is a major task for the global agricultural sector [1]. Economic growth, social equity, and environmental protection are three fundamental components of sustainable development [2]. In the area of agriculture, the goals of sustainable development are to improve agricultural productivity, ensure food security, reduce poverty and malnutrition, and conserve natural resources, thereby simultaneously 
taking account of economic efficiency, social benefits and environmental sustainability [3,4]. Improving agricultural productivity and promoting sustainable agricultural development is a more pressing concern for developing countries with higher rates of food insecurity, malnutrition, and rural poverty $[5,6]$.

The importance of agricultural sustainable development is particularly high in south Asia and southeast Asia. Agriculture has long occupied a particularly important position in the economic and social development of south and southeast Asian countries, which has exclusively contributed to providing employment, improving food security, and reducing poverty in these two regions [6-8]. Over recent decades, south Asia and southeast Asia have undergone rapid economic growth and extensive structural changes. Based on the statistics of World Bank data presented in Table 1, the average GDP growth rate of south Asia and southeast Asia were 5.5\% and 6.3\% per year, respectively, during the period 2003-2016. However, the growth rate of agriculture on average was only around 3.2\% for south and southeast Asia during the same period. Southeast Asian countries even experienced a reduced production in agriculture with an average growth rate of $-0.08 \%$ in 2016 . Furthermore, the share of agriculture in GDP is shrinking over time, while that of services and manufacture is increasing. Agriculture's share of GDP in south and southeast Asian countries reduced from $22 \%$ in 2003 to less than $19 \%$ in 2016. The slowing growth and declining share of agriculture raises attention to the importance of promoting sustained agricultural growth in these two regions. Despite the decline of agriculture's share in the economy, agricultural employment still accounted for around $47.4 \%$ and $38.9 \%$ of total employment in major south Asian and southeast Asian countries, respectively, during the period 2003-2016. Comparatively, the share of agricultural employment in south Asia is higher than in southeast Asia.

Table 1. Agriculture development in south and southeast Asian countries.

\begin{tabular}{ccccc}
\hline Year & $\begin{array}{c}\text { GDP Growth } \\
\text { (Annual \%) }\end{array}$ & $\begin{array}{c}\text { Agriculture Growth } \\
\text { (Annual \%) }\end{array}$ & $\begin{array}{c}\text { Agriculture, Value } \\
\text { Added (\% of GDP) }\end{array}$ & $\begin{array}{c}\text { Agriculture Employment } \\
\text { (\% of Total Employment) }\end{array}$ \\
\hline \multicolumn{5}{c}{ South Asia } \\
\hline 2003 & 6.27 & 4.01 & 22.06 & 52.56 \\
mean & 6.77 & 2.51 & 16.90 & 42.82 \\
\hline \multicolumn{5}{c}{ Southeast Asia } \\
\hline 2003 & 7.54 & 7.48 & 21.68 & 47.35 \\
2016 & 6.50 & -0.08 & 15.23 & 46.05 \\
mean & 6.30 & 3.20 & 18.89 & 32.21 \\
\hline
\end{tabular}

Note: The statistics are based on data from eight south Asian countries (Afghanistan, Bangladesh, Bhutan, India, Iran, Nepal, Pakistan and Sri Lanka) and seven southeast Asian countries (Cambodia, Indonesia, Malaysia, Myanmar, the Philippines, Thailand, Vietnam) from the World Bank database.

It is obvious that the sustainable development of agriculture in south and southeast Asia faces plenty of challenges. First, there is increasing domestic and foreign demand for food due to continued economic growth, rising population and increasing involvement in international trade $[4,9]$. Second, there are frequent losses of agricultural labor force and arable land because of extensive structural changes and urbanization [10]. In addition, climate change and natural disasters have led to land degradation and reductions in water availability, which impose pressure on agricultural production [11,12]. Furthermore, food insecurity, malnutrition and rural poverty remain as issues to be addressed in south and southeast Asian countries [13]. Therefore, how to guarantee adequate food supply and sustainable agriculture production under these aforementioned challenges is an arduous task for the agricultural sectors in south and southeast Asia.

Faced with growing food demand with limited agricultural land and labor resources, enhancing agricultural productivity becomes the most indispensable and effective solution to increase agricultural production, ensure food security, reduce poverty and malnutrition, and maintain environmental 
sustainability in these two regions. Agricultural total factor productivity (TFP) is viewed as a representative indicator to assess sustainable development of the agricultural sector [6]. Although the concept of sustainability incorporates biophysical, economic and social dimensions, we focus on the economic and social dimensions of sustainability because time series data on biophysical aspects of agriculture for our study regions are not available, a point also raised by Anik et al. [6] when analyzing agricultural productivity growth and sustainability in four South Asian countries. As an appropriate measure to assess sustainability, agricultural TFP should have a non-negative trend in a sustainable production system. This is because agricultural TFP ensures production by taking advantage of technological progress, promoting the effective utilization of resources, and saving the economic and environmental costs of agricultural production [14]. Therefore, a clear map of agricultural productivity growth and the identification of its influencing factors are crucial to assess the sustainability of agricultural production in south and southeast Asian countries for the future.

Given the above background, the objectives of this study are twofold. The first is to estimate the annual growth of agricultural TFP for eight south Asian countries (Afghanistan, Bangladesh, Bhutan, India, Iran, Nepal, Pakistan and Sri Lanka) and seven southeast Asian countries (Cambodia, Indonesia, Malaysia, Myanmar, the Philippines, Thailand, Vietnam) using country-level data covering the period 2002-2016. Cross-country comparisons for south and southeast Asia can be useful as countries in the two regions have many similarities in terms of geography, production practices and policies, and economic and social environments $[6,15]$. The selected 15 countries are all traditional agricultural countries in south and southeast Asia, and thus are typical and representative examples to study and compare agricultural development between regions and countries. Based on stochastic frontier analysis (SFA), the growth of agricultural TFP will be decomposed into three sources: technical change, technical efficiency change, and scale change, thereby enabling a clear understanding of the different changing patterns of agricultural TFP in different countries and over time. The second objective is to identify the key socio-economic factors influencing the growth of agricultural productivity in south and southeast Asia, which could shed new light on explaining agricultural growth from the viewpoints of social and economic indicators, thereby providing relevant policy recommendations to promote agricultural productivity growth under the goal of sustainable development.

\section{Literature Review}

Total factor productivity (TFP) is a broad measure of agricultural productivity performance. TFP explains how efficiently inputs are utilized in production under the influence of technology, policy, trade, and other various factors [16]. TFP can be decomposed into the different shares explained by each component of productivity growth, which helps to identify the different sources of productivity growth, such as technical change, technical efficiency change, and scale efficiency change $[17,18]$.

There have been numerous studies focusing on the agricultural productivity of developing countries, and many of them paid attention to the region or countries of sub-Saharan Africa [18-20] and China [21-23]. Relatively less research has been conducted on agricultural productivity of south and southeast Asian countries. Sujan et al. [15] analyzed the agricultural productivity of ten south and southeast Asian countries from 1980 to 2007 and concluded that southeast Asia experienced a higher growth rate in agricultural production than south Asia. Anik et al. [6] assessed TFP and its six efficiency components for four south Asian countries, Bangladesh, India, Nepal, and Pakistan, for the period 1980 to 2013. Their results revealed that the agricultural productivity of these four countries experienced sustained growth. There have also been some studies focusing on the agricultural productivity of individual countries, such as Bangladesh [24], India [25-28] and Nepal [29] in south Asia, and Indonesia [30] and Vietnam [31-33] in southeast Asia.

Regarding the factors affecting agricultural productivity, empirical studies first suggested that indicators of economic development, such as income level, urbanization, and industrialization, were crucial determinants of agricultural TFP growth [25,34-36]. Second, many studies found that human capital positively contributed to the growth of agricultural productivity $[6,36,37]$. Third, 
agricultural trade affects productivity significantly, although conclusions in this regard have been ambiguous. Some studies have shown that agriculture trade, both import and export, has positive influence on agricultural productivity through international spillovers [38,39], while other researchers have argued that international competition may cause an exodus of human and physical capital from local firms, leading local agricultural firms to become less productive [40]. In addition, financial development and assistance to agriculture were also found to be essential to the growth of agricultural productivity, although conclusions were mixed. Zakaria et al. [36] and Ssozi et al. [41] suggested that there is a positive relationship between financial development and agricultural productivity, while Anik et al. [6] found financial capital to have a negative sign as a determinant of agricultural TFP. In addition, factors such as research, government spending, institutional quality, and climate have also been identified as key determinants of agricultural productivity.

As for research methods, stochastic frontier analysis (SFA) and data envelopment analysis (DEA) were the most used tools in the field of productivity estimation. Compared with traditional index number approaches, such as Fisher's (1922) and Törnqvist's (1936) productivity indices, SFA (parametric approach) and DEA (non-parametric approach) do not require price information or technical and behavioral assumptions [17]. A great deal of studies have applied DEA to estimate agricultural productivity, such as Anik et al. [6], Rezitis [42], and Li et al. [43]. However, some scholars have argued that DEA-derived TFP always draws inconsistent conclusions, as DEA cannot distinguish productivity from measurement errors and white noise [22,23]. Moreover, the issues regarding random or measurement errors are especially prominent for productivity analysis at the macro level [44]. Instead, SFA allows the separation of inefficiency from random shocks or measurement errors, thus providing a more accurate estimate of efficiency [18,45]. Given this advantage, SFA has been applied in various studies to analyze agricultural productivity and its components, such as by Benedetti et al. [46], Adetutu and Ajayi [18], and Gong [23].

Existing studies have provided valuable theoretical foundations and empirical findings on agricultural productivity and its influencing factors. However, despite the important roles of south and southeast Asia in the world economy and agriculture, not much insight has been gained into the agricultural productivity and sustainability of south and southeast Asian countries. Also, research has seldom investigated the influencing factors on agricultural productivity in south and southeast Asia. The contributions of this study to the related literature are as follows. First, this study compensates for the lack of literature on agricultural productivity and its influencing factors for south and southeast Asian countries at regional levels. By comparing differences in agricultural productivity growth and its components across regions and countries, a more comprehensive understanding of the agricultural development of south and southeast Asia is gained. Second, most studies of the agricultural productivity of south Asia and southeast Asia were carried out by nonparametric approach. We adopt the stochastic production frontier model to estimate agricultural productivity, which can separate measurement errors from estimated efficiency scores, thereby providing new evidence to support the related literature under a parametric analytical framework.

\section{Methodology and Data}

\subsection{Decomposition of Total Factor Productivity}

Following Kumbhakar and Lovell [17], stochastic frontier analysis (SFA) was employed for the estimation and decomposition of TFP changes. A single-output stochastic production frontier model can be expressed as

$$
y_{i t}=f\left(X_{i t}, t, \beta\right) \exp \left(-u_{i t}\right),
$$

where $y_{i t}$ represents the value of agricultural production of country $i$ in time $t$, and $X_{i t}$ donates the set of input variables. A time trend variable $t$ is included to capture technology progress arising from exogenous sources. The error component $u_{i t}$ measures technical inefficiency, which is a non-negative random variable and assumed to have a half-normal distribution in our study. 
Taking the logarithm for both sides of Equation (1), we get

$$
\ln y_{i t}=\ln f\left(X_{i t}, t, \beta\right)-u_{i t}
$$

The technical efficiency of production for country $i$ in time $t$ is expressed as

$$
T E_{i t}=\exp \left(-u_{i t}\right)
$$

The productivity change is defined as

$$
\operatorname{TFP}=\dot{y}-\dot{X}=\dot{y}-\sum_{j=1}^{J} S_{j} x_{j}
$$

where the dot represents the rate of change, $S_{j}=\frac{w_{j} x_{j}}{E}$ is the expenditure share of inputs $x_{j}, w_{j}$ donates price of inputs $x_{j}$, and total expenditure is expressed as $E=\sum_{j} w_{j} x_{j}$.

According to Equation (2), the rate of change of production $y$ is derived by

$$
\dot{y}=\frac{\partial \ln y}{\partial t}=\frac{\partial \ln f(X, t, \beta)}{\partial t}+\sum_{j=1}^{J} \frac{\partial \ln f(X, t, \beta)}{\partial \ln x_{j}} \cdot \frac{\partial \ln x_{j}}{\partial x_{j}} \cdot \frac{d x_{j}}{d t}-\frac{\partial u}{\partial t} .
$$

Equation (5) can be written as

$$
\dot{y}=\frac{\partial \ln f(X, t, \beta)}{\partial t}+\sum_{j} \varepsilon_{j} \dot{x}_{j}-\frac{\partial u}{\partial t}
$$

The symbol $\varepsilon_{j}$ represents the elasticities of output with respect to each input: the total elasticities of output sum to $\varepsilon=\sum_{j} \varepsilon_{j}$, which can also be regarded as the return to scale index. Substituting Equation (6) into Equation (4), we get

$$
T \dot{F P}=\frac{\partial \ln f(X, t, \beta)}{\partial t}+(\varepsilon-1) \sum_{j} \xi_{j} \dot{x}_{j}+\sum_{j}\left(\xi_{j}-S_{j}\right) \dot{x}_{j}-\frac{\partial u}{\partial t}
$$

where $\xi_{j}=\varepsilon_{j} / \varepsilon$. However, the information on input prices is not available. Thus, it can be simply assumed that $\xi_{j}=S_{j}$ for all $j$. Then, the decomposition of TFP change (TFPC) can be simplified to

$$
T F P C=\frac{\partial \ln f(X, t, \beta)}{\partial t}+(\varepsilon-1) \sum_{j} \xi_{j} \dot{x}_{j}-\frac{\partial u}{\partial t} .
$$

In Equation (8), technical change (TC) is represented as

$$
T C=\frac{\partial \ln f(X, t, \beta)}{\partial t} .
$$

Positive values of TC imply technical progress. The scale change (SC) component is calculated by

$$
S C=(\varepsilon-1) \sum_{j} \xi_{j} \dot{x}_{j}
$$

If $\varepsilon-1>0$, it implies increasing returns to scale, and the expansion of inputs use will contribute to the growth of productivity. Diseconomies of scale occur when $\varepsilon-1<0$, and the increase of inputs use will result in the deterioration of productivity. The rate of technical efficiency change (TEC) is given by

$$
T E C=-\frac{\partial u}{\partial t} .
$$

A positive value of TEC represents a reduction in inefficiency. 
Now, the changes in TFP have been decomposed into three components, technical change, technical efficiency change and scale change, which can be written as

$$
T F P C=T C+S C+T E C .
$$

Scale change represents changes in the scale of production, which can be understood as movements towards or away from the optimal scale. Technical change can be understood as improvements in best practices, while technical efficiency change measures the extent to which actual production practices move closer to best practices.

The translog production frontier model with four inputs is expressed as

$$
\begin{gathered}
\ln y_{i t}=\beta_{0}+\sum_{j=1}^{4} \beta_{j} \ln x_{j i t}+\beta_{t} t+\frac{1}{2} \sum_{j=1}^{4} \sum_{k=1}^{4} \beta_{j k} \ln x_{j i t} \ln x_{k i t}+\frac{1}{2} \beta_{t t} t^{2} \\
+\sum_{j=1}^{4} \beta_{i t} \ln x_{j i t} t+\alpha_{r} D_{r}+v_{i t}-u_{i t} .
\end{gathered}
$$

where $y_{i t}$ is the agricultural production value added of country $i$ and time $t, x_{j i t}$ is the $\mathrm{j}$-th agricultural input factor, and $t$ is the time trend variable. Further, we added a regional dummy variable $D_{r}$ to capture unobserved regional heterogeneities.

Following Battese and Coelli [47], the inefficiency term $u_{i t}$ is defined as

$$
u_{i t}=u_{i} \exp (-\eta[t-T]),
$$

where $u_{i}$ represents the technical inefficiency effect for the i-th production unit which is assumed to be half-normally distributed in this study, and $\eta$ represents the rate of change in technical efficiency. Positive values of $\eta$ indicate improvements in technical efficiency over time [48].

\subsection{Dynamic Panel Data Models}

The first-difference generalized method of moments (FD-GMM) estimator and system generalized method of moments (SYS-GMM) estimators in dynamic panel data models were applied to explain the determinants of agricultural productivity growth in south and southeast Asian countries. The basic form of a dynamic panel data model is given by

$$
y_{i t}=\gamma y_{i, t-1}+\beta X_{i t}+\alpha_{i}+\varepsilon_{i t},|\gamma|<1
$$

where $y_{i t}$ indicates changes of agricultural TFP for country $i(i=1,2, \ldots, N)$ at time $t(t=$ $2,3, \ldots, T), X_{i t}=\left(x_{1 i t}, x_{2 i t}, \ldots, x_{k i t}\right) \prime$ is a vector of $k$ explanatory variables that explains TFP changes, and $\gamma$ and $\beta$ are parameters to be estimated. The fixed effects decompositions of the error term are represented by $\left(\alpha_{i}+\varepsilon_{i t}\right)$, and $\alpha_{i}$ is the so-called individual-specific error which captures unobserved effects that are different across countries but fixed across time. Taking the first differences of Equation (15) to eliminate individual effects, we get the first difference equation:

$$
\Delta y_{i t}=\gamma \Delta y_{i, t-1}+\beta \Delta X_{i t}+\Delta \varepsilon_{i t} .
$$

In Equation (16), $\Delta y_{i, t-1}$ is endogenous because it is correlated with $\Delta \varepsilon_{i t}$. To solve this problem of endogeneity, Anderson and Bond [49] proposed the FD-GMM estimator, which is also called the Arellano-Bond estimator. The FD-GMM estimator applies all possible lags of $y_{i, t-1}$ and $X_{i t}$ to construct an instrument matrix under the moment conditions $E\left(y_{i, t-2} \Delta \varepsilon_{i t}\right)=0$ and $E\left(x_{i, t-1} \Delta \varepsilon_{i t}\right)=0$. 
The instrument matrix $W_{i}^{d}$ for estimating the difference of Equation (16) under the two moment conditions can be expressed by

$$
W_{i}^{d}=\left[\begin{array}{cccccccc}
y_{i 1} & 0 & 0 & \cdots & 0 & \cdots & 0 & X^{\prime}{ }^{2} \\
0 & y_{i 1} & y_{i 2} & \cdots & 0 & \cdots & 0 & X_{i 3}^{\prime} \\
\vdots & \vdots & \vdots & \cdots & \vdots & \cdots & \vdots & \vdots \\
0 & 0 & 0 & \cdots & y_{i 1} & \cdots & y_{i, T-2} & X_{i, T-1}^{\prime}
\end{array}\right],
$$

where $\left(y_{i 1}, y_{i 2}, \ldots, y_{i, t-2}\right)$ indicate the GMM-type instruments at time $t$ which contribute to multiple columns of the instrument matrix. In addition, the first differences of all exogenous variables $X_{i t}$ are applied as standard instruments. Using the instrument matrix $W_{i}^{d}$, Equation (16) can be estimated under the GMM framework. Detailed explanations and the proof process of the FD-GMM estimator can be referred to in Anderson and Bond [49] and Carstensen and Toubal [50].

The SYS-GMM estimator, proposed by Blundell and Bond [51], is a system estimation of both the level equation (Equation (15)) and the first difference equation (Equation (16)). The SYS-GMM estimator uses additional moment conditions $E\left(\Delta y_{i, t-1} \varepsilon_{i t}\right)=0$ and $E\left(\Delta x_{i, t-1} \varepsilon_{i t}\right)=0$ to improve the small sample performance of the FD-GMM estimator. The corresponding instrument matrix for the level equation is given by

$$
W_{i}^{l}=\left[\begin{array}{ccccc}
\Delta y_{i 2} & 0 & \cdots & 0 & \Delta x \prime_{i 2} \\
0 & \Delta y_{i 3} & \cdots & 0 & \Delta x_{i 3} \\
\vdots & \vdots & \cdots & \vdots & \vdots \\
0 & 0 & \cdots & \Delta y_{i, T-1} & \Delta x_{i, T-1}
\end{array}\right]
$$

Then, the system instrument matrix can be obtained by

$$
W_{i}^{l}=\left[\begin{array}{cc}
W_{i}^{d} & 0 \\
0 & W_{i}^{l}
\end{array}\right]
$$

The SYS-GMM estimator provides an alternative to the FD-GMM estimator; for detailed explanations see Blundell and Bond [51] and Carstensen and Toubal [50].

\subsection{Data Descriptions}

To estimate the production frontier function described above, data on the net agriculture production value added were used to represent agricultural output. Following Fuglie [52] and Adetutu and Ajayi [18], we considered four agricultural inputs to estimate the production frontier, which were land, labor, capital, and fertilizer. Agricultural land referred to land used for cultivation of crops and animal husbandry. Agricultural labor was represented by total population working in agriculture. Capital input was proxied by the net capital stocks, which reflect physical investment flows after deducting the portion of assets that are depreciated. The net capital stocks of agriculture were deflated and transformed from the values of current local currencies to constant 2005 international dollars. After land, labor, and capital, material inputs also need to be taken into account when estimating agricultural productivity and efficiency. Fertilizer is a commonly used material input during the agricultural production process, which is measured as the sum of nutrient nitrogen $(N)$, phosphate $\left(\mathrm{P}_{2} \mathrm{O}_{5}\right)$, and potash $\left(\mathrm{K}_{2} \mathrm{O}\right)$. Considering data availability, fertilizer use was selected as a representation of material inputs into the estimation of agricultural productivity. We did not use seed because reliable information on seed for all countries under consideration is limited. Furthermore, seed tends to be used in fixed proportion relative to the amount of land cultivated, and therefore creates a problem of collinearity with the land variable under the parametric estimation method. 
Based on the existing literature and data availability, we considered six variables to explain the changes in agricultural TFP. These variables were income level [34,36], human capital [6,36,37], agricultural export and import [38-40], level of urbanization [25,35] and development flow to agriculture $[6,36,41]$. Income level was represented by GDP per capita, which was converted into 2005 international dollars. Mean years of schooling was used as a proxy for human capital. Agricultural export (import) was calculated as the ratio of agricultural export (import) value to GDP. The urbanization level was proxied by the ratio of urban population to total population. Furthermore, we applied the shares of development flow to agriculture to investigate the influence of agricultural aid from all donors on changes of TFP. The data on development flow to agriculture (DFA) provided by the Food and Agriculture Organization of the United Nations (FAO) is composed of official development assistance (ODA) flows, other official flows (OOFs), and private grant/flows from donor countries.

We collected country-specific data on agricultural output and input variables from eight south Asian countries and seven southeast Asian countries covering a 15-year period of 2002-2016 to estimate changes of agricultural TFP. Therefore, a total of 225 observations were included in our data set. Subsequent changes in the agricultural TFP of these 15 countries from 2003 to 2016 were obtained by employing SFA. Afterwards, variables explaining TFP changes collected from our sample countries during 2003-2016 were used to identify the determinants of agricultural productivity growth using dynamic panel data models. The descriptions and data sources of all variables are presented in Table 2, and descriptive statistics of the variables are displayed in Table 3. The logarithm forms of agricultural production, the four agricultural inputs, and GDP per capita were applied in the estimations.

Table 2. Descriptions of variables with data sources.

\begin{tabular}{|c|c|}
\hline Variables & Description of Variables and Source of Data \\
\hline & Agricultural Output and Inputs \\
\hline Agricultural production & $\begin{array}{l}\text { Net agriculture production value added in millions of 2004-2006 international } \\
\text { dollars collected from the Food and Agriculture Organization of the United } \\
\text { Nations (FAO). }\end{array}$ \\
\hline Labor & $\begin{array}{l}\text { Total population working in agriculture calculated based on agriculture } \\
\text { employment data from the World Bank (WB) database (modeled International } \\
\text { Labour Organization (ILO) estimated). }\end{array}$ \\
\hline Land & Agriculture land area (1000 hectare) from FAO. \\
\hline Capital & $\begin{array}{l}\text { Net capital stocks of agriculture in millions of } 2005 \text { international dollars } \\
\text { from FAO. }\end{array}$ \\
\hline Fertilizer & $\begin{array}{l}\text { Total value of nutrient nitrogen }(\mathrm{N}) \text {, nutrient phosphate }\left(\mathrm{P}_{2} \mathrm{O}_{5}\right) \text { and nutrient } \\
\text { potash }\left(\mathrm{K}_{2} \mathrm{O}\right) \text { for agriculture use (tons) from FAO. }\end{array}$ \\
\hline Regional dummy & $D=1$ for south Asian countries, 0 otherwise. \\
\hline \multicolumn{2}{|r|}{ Determinants of Agricultural Total Factor Productivity Change } \\
\hline GDP per capita & GDP per capita from WB (converted into 2005 international dollars). \\
\hline Human capital & $\begin{array}{l}\text { Mean years of schooling from Human Development Data (1990-2018) from } \\
\text { United Nations Development Program. }\end{array}$ \\
\hline Agricultural export & Ratio of agricultural export value to GDP from FAO. \\
\hline Agricultural import & Ratio of agricultural import value to GDP from FAO. \\
\hline Urbanization & Urban population ( $\%$ of total population) from WB. \\
\hline Development flow & Share of total aid to agriculture to total development flow from FAO. \\
\hline
\end{tabular}


Table 3. Descriptive statistics of variables.

\begin{tabular}{cccccc}
\hline Variables & Obs. & Mean & Std. Dev. & Min & Max \\
\hline Agricultural Outputs and Inputs (2002-2016) \\
\hline Agriculture production (millions $\$ 2005$ ppp) & 225 & 31,168 & 52,198 & 160.8 & 261,429 \\
Land (1000 hectare) & 225 & 29,554 & 43,749 & 519.0 & 180,560 \\
Capital (millions $\$ 2005$ ppp) & 225 & 107,341 & 228,271 & 160.0 & $1,219,638$ \\
Fertilizer (tons) & 225 & $28,01,040$ & $5,775,778$ & 1010 & $28,373,686$ \\
\hline Determinants of Agricultural Total Factor Productivity & Change (2003-2016) \\
\hline GDP per capita (\$2005 ppp) & 210 & 4469.2 & 3894.9 & 744.8 & $17,429.6$ \\
Human capital (years) & 210 & 6.151 & 2.545 & 2.300 & 11.000 \\
Agriculture export (\%) & 210 & 3.217 & 2.703 & 0.171 & 11.985 \\
Agriculture import (\%) & 210 & 7.510 & 4.163 & 1.718 & 20.088 \\
Urbanization (\%) & 210 & 36.41 & 16.30 & 14.54 & 74.84 \\
Development flow to agriculture (\%) & 210 & 5.828 & 5.406 & 0.180 & 41.17 \\
\hline
\end{tabular}

\section{Results and Discussion}

\subsection{Drivers of Agricultural Production: Stochastic Production Frontier Model Results}

The estimated results of the production function by SFA are presented in Table 4. The estimated coefficients represent elasticities of agricultural output with respect to inputs. The coefficient of Labor is 0.1799 , implying that a $1 \%$ increase in agriculture labor on average will increase agricultural output by $0.18 \%$. Similarly, the elasticities of agricultural output with respect to Land (Fertilizer) are $0.60 \%$ $(0.06 \%)$, indicating that a $1 \%$ increase in agricultural land (fertilizer) will increase agricultural output by $0.60 \%(0.06 \%)$. It can be concluded that the agricultural outputs of south and southeast Asian countries in our sample were most sensitive to changes in agricultural land, followed by changes in agricultural labor and fertilizer. However, the estimated coefficient of Capital is positive but not statistically significant, indicating that capital formulation in agriculture has not made obvious and significant contributions to the growth of agricultural output. Moreover, the coefficient of the time trend variable (Time) is positive and significant, while the coefficient of Time squared is significantly negative. This result indicates that the changes in agricultural productivity in our sample countries experienced a nonlinear trend, which increased at the beginning and started to decrease after reaching a certain point. Moreover, the coefficient of the regional dummy variable is negative and significant at $1 \%$ level, implying that south Asian countries experienced a lower growth rate of agriculture output than southeast Asian countries.

Table 4. Estimation results of production function.

\begin{tabular}{ccc}
\hline Variables & Coef. & Std. Error \\
\hline Labour & $0.1799^{* * *}$ & 0.0267 \\
Land & $0.6049^{* * *}$ & 0.0357 \\
Capital & 0.0223 & 0.0441 \\
Fertilizer & $0.0583^{*}$ & 0.0299 \\
Labour squared & $0.4343^{* * *}$ & 0.0314 \\
Land squared & $-0.8832^{* * *}$ & 0.0611 \\
Capital squared & $-0.5349^{* * *}$ & 0.1015 \\
Fertilizer squared & -0.0102 & 0.0222 \\
Labour*Land & -0.0463 & 0.0349 \\
Labour*Capital & -0.0113 & 0.0424 \\
Labour ${ }^{*}$ Fertilizer & $-0.0521^{* *}$ & 0.0203 \\
Land Capital & $0.5283^{* * *}$ & 0.0564 \\
Land $^{*}$ Fertilizer & -0.0168 & 0.0253 \\
Capital*Fertilizer & 0.0313 & 0.0475 \\
\hline
\end{tabular}


Table 4. Cont.

\begin{tabular}{|c|c|c|}
\hline Variables & Coef. & Std. Error \\
\hline Time & $0.0457 * * *$ & 0.0067 \\
\hline Time squared & $-0.0043^{* * *}$ & 0.0008 \\
\hline Labour*Time & $0.0119^{* * *}$ & 0.0026 \\
\hline Land ${ }^{*}$ Time & $-0.0196^{* * *}$ & 0.0040 \\
\hline Capital ${ }^{*}$ Time & $0.0213^{* * *}$ & 0.0054 \\
\hline Fertilizer*Time & -0.0018 & 0.0032 \\
\hline Region dummy & $-0.2596^{* * *}$ & 0.0262 \\
\hline $\begin{array}{c}\text { Constant } \\
\sigma_{u}^{2}\end{array}$ & $0.3125^{* * *}$ & 0.0310 \\
\hline trend & $-0.0655^{*}$ & 0.0388 \\
\hline $\begin{array}{c}- \text { cons } \\
\sigma_{v}^{2}\end{array}$ & $-3.0465^{* * *}$ & 0.3021 \\
\hline _cons & $-6.5340 * * *$ & 0.5796 \\
\hline Log-likelihood & 197.45 & \\
\hline
\end{tabular}

Note: the variables of inputs and outputs have been normalized by subtracting local mean value; significance at the $0.01,0.05$, and 0.10 levels is indicated by ${ }^{* * *}, * *$, and $*$, respectively.

\subsection{Agricultural Total Factor Productivity Growth and Its Decomposition}

The agricultural TFP growth was decomposed into scale change (SC), technical change (TC), and technical efficiency change (TEC) according to the method described in Section 3.1. The annual changes in TFP (TFPC) and its components are presented in Table 5. Positive values of TFPC indicate improvements of TFP, whereas the negative values represent the deterioration of productivity performance.

Table 5. Annual changes in total factor productivity (TFPC) in agriculture and its components: scale change (SC), technical change (TC), and technical efficiency change (TEC).

\begin{tabular}{ccccc}
\hline Year & TFPC & SC & TC & TEC \\
\hline 2003 & 0.0244 & -0.0024 & 0.0321 & -0.0053 \\
2004 & -0.1263 & -0.1496 & 0.0284 & -0.0052 \\
2005 & 0.0047 & -0.0158 & 0.0256 & -0.0050 \\
2006 & -0.0191 & -0.0364 & 0.0221 & -0.0048 \\
2007 & 0.0257 & 0.0119 & 0.0184 & -0.0047 \\
2008 & -0.0070 & -0.0172 & 0.0148 & -0.0045 \\
2009 & 0.0436 & 0.0372 & 0.0108 & -0.0044 \\
2010 & -0.0043 & -0.0071 & 0.0071 & -0.0042 \\
2011 & 0.0200 & 0.0208 & 0.0033 & -0.0041 \\
2012 & -0.0298 & -0.0264 & 0.0005 & -0.0040 \\
2013 & -0.0172 & -0.0104 & -0.0029 & -0.0038 \\
2014 & -0.0485 & -0.0385 & -0.0062 & -0.0037 \\
2015 & 0.0011 & 0.0147 & -0.0099 & -0.0036 \\
2016 & -0.0175 & -0.0004 & -0.0135 & -0.0035 \\
Mean & -0.0107 & -0.0292 & 0.0093 & -0.0043 \\
\hline
\end{tabular}

Note: the mean values of changes in agricultural TFP and its components are presented; the year 2003 refers to the changes between 2002 to 2003 .

We observed that agricultural TFP in south and southeast Asian countries on average decreased by $1.07 \%$ from 2003 to 2016 . The changes in agricultural TFP were not stable over time. In some years we witnessed improvements in productivity. For other years, however, the agricultural TFP decreased on average. The average scale change was $-2.92 \%$ which was the major source of the deterioration of agricultural productivity. In most years, the values of SC were always negative, indicating that agricultural TFP in general has not benefited from economies of scale. On the contrary, technical change on average improved by $0.93 \%$, which implies that technical progress contributed to the improvement 
of agricultural productivity in south and southeast Asia. The value of TC remained positive from 2003 to 2012 with a decreasing trend, while it turned negative after 2012. This result reflects a slowdown of technical progress in the agricultural sectors of the sample countries. On the other hand, the technical efficiency change, with an average annual rate of $-0.43 \%$, also resulted in a decrease of TFP. The values of TEC remained negative every year, implying that there was a persistent increase in inefficiency. To summarize, technical progress is the only source that contributed to the growth of agricultural productivity, whereas declining scale and technical efficiency changes both resulted in the decline of agriculture TFP in south and southeast Asian countries.

Next, we disentangled the estimations of agricultural TFP and its components at region and country levels, to understand the region and country-specific characteristics of agricultural productivity growth. Table 6 displays the changes in agricultural TFP and its components for the 15 south and southeast Asian countries. At the regional level, we found a negative average growth rate $(-2.96 \%)$ in agricultural TFP for south Asia, indicating an unsustainable route of agricultural development. On the contrary, the agricultural TFP of southeast Asian countries on average increased by $1.08 \%$ during the sample period. The decrease in agricultural TFP in south Asian countries was largely due to the negative scale change $(-3.06 \%)$. On the contrary, technical change, with an average growth rate of $0.54 \%$, was the major source of agricultural productivity growth. As for southeast Asia, scale change and technical change, with average growth rates of $0.13 \%$ and $1.38 \%$ respectively, both contributed to agricultural TFP growth. Like south Asia, technical progress was also the major source driving the improvement of agricultural TFP in southeast Asian countries.

Table 6. Changes in total factor productivity (TFPC) and its components by country.

\begin{tabular}{cccccccc}
\hline Countries & TFPC & SC & TC & Countries & TFPC & SC & TC \\
\hline \multicolumn{7}{c}{ South Asia } \\
\hline Afghanistan & -0.1059 & -0.0679 & -0.0336 & Cambodia & -0.0267 & 0.0033 & -0.0256 \\
Bangladesh & 0.0196 & -0.0022 & 0.0262 & Indonesia & 0.0380 & 0.0034 & 0.0390 \\
Bhutan & -0.0486 & 0.0121 & -0.0564 & Malaysia & 0.0075 & -0.0026 & 0.0144 \\
India & 0.0691 & 0.0091 & 0.0643 & Myanmar & 0.0013 & 0.0048 & 0.0009 \\
Iran & -0.2088 & -0.1988 & -0.0056 & Philippines & 0.0257 & -0.0003 & 0.0303 \\
Nepal & 0.0062 & 0.0037 & 0.0068 & Thailand & 0.0090 & 0.0001 & 0.0133 \\
Pakistan & 0.0321 & -0.0008 & 0.0373 & Vietnam & 0.0208 & 0.0005 & 0.0247 \\
Sri Lanka & -0.0002 & 0.0004 & 0.0038 & & & & \\
Mean & -0.0296 & -0.0306 & 0.0054 & Mean & 0.0108 & 0.0013 & 0.0138 \\
\hline
\end{tabular}

Note: the value of technology efficiency change (TEC) is -0.0043 , which is a constant for all countries; SC: scale change; TC: technical change.

Regarding specific countries in south Asia, Bangladesh, India, Pakistan, and Nepal in general all experienced improvements in agricultural productivity during the sample period. This result is supported by Anik et al. [6] who also found a positive growth rate for agricultural TFP for Bangladesh, India, and Pakistan during the period 2001-2013. The estimated growth rate of agricultural TFP for India $(6.91 \%)$ was the highest among south Asian countries, followed by Pakistan (3.21\%), Bangladesh $(1.96 \%)$, and Nepal $(0.62 \%)$. Technical change contributed most to the growth of agricultural TFP for all four countries. India plays a leading role in the economy of south Asian countries and is a major food producer and consumer. The high growth rate of agricultural TFP in India can not only contribute to maintaining the self-sufficiency of Indian agricultural production, but also help to meet the additional food demand of its neighboring countries.

On the contrary, we found negative growth rates of agricultural TFP in Afghanistan ( $-10.59 \%)$, Bhutan $(-4.86 \%)$, and Iran $(-20.88 \%)$. The sharp decline of scale efficiency was the major cause for the deterioration of agricultural productivity in both Afghanistan and Iran. In the past decades, the agriculture of Afghanistan and Iran has faced many challenges due to prolonged conflicts and natural disasters. The shortage of water, lack of irrigation land, and devastating damage to rural 
infrastructure have resulted in the loss of scale efficiency and largely held back agricultural productivity. Unlike Afghanistan and Iran, the decline of agricultural TFP in Bhutan resulted from the obvious reduction in technical efficiency $(-5.64 \%)$. Minten and Dukpa [53] also mentioned that the low level of technology led to low agricultural productivity in Bhutan. Therefore, promoting technical innovation and progress should be the primary task for Bhutan to achieve the sustainable development of agriculture.

As for southeast Asia, except for Cambodia, the other six southeast Asian countries all experienced improvements in agricultural productivity. The growth rate of agricultural TFP for Indonesia $(3.80 \%)$ was the highest, followed by the Philippines $(2.57 \%)$, Vietnam $(2.08 \%)$, Thailand $(0.90 \%)$, and Malaysia $(0.75 \%)$. Like south Asia, technical progress made the dominant contribution to improving the agricultural TFP in these five countries. The growth rate of agricultural TFP in Myanmar was only $0.13 \%$. Unlike the other five countries, the scale change $(0.48 \%)$ largely contributed to agricultural TFP growth, while technical efficiency change was the major factor holding back the agricultural productivity of Myanmar.

Cambodia is the only country in southeast Asia that experienced an average drop of $-2.67 \%$ in agricultural productivity during the sample period. The retrogression of technology in Cambodia was the main reason for the deterioration of agricultural productivity, a somewhat similar situation to that of Bhutan. In comparison with south Asian countries, southeast Asian countries overall showed a more sustained and stable growth in agricultural productivity, which is in accordance with the findings by Sujan et al. [15] who concluded that the average agricultural production growth was higher in southeast Asia than south Asia.

To explain the changing characteristics of agricultural TFP for each country more intuitively, the annual TFP changes and their three components for south Asian and southeast Asian countries are plotted in Figure 1; Figure 2, respectively. As shown in Figure 1, the agricultural TFP exhibited similar growth patterns in Bangladesh, India, and Pakistan. Each country observed a positive growth rate of agricultural TFP every year, with considerable contributions due to technical progress. The continued TFP growth indicated that the development of agricultural productivity in the three countries was relatively steady and robust. Technical change was rising continuously throughout the sample period, indicating continuous improvements in the technological innovation of the agricultural sectors in the three countries. Thus, we can conclude that the agricultural developments of Bangladesh, India, and Pakistan were at the forefront among the south Asian countries. However, it should be noted that the growth speed of agricultural TFP in the three countries was decreasing along with technical progress. As a result, how to provide enough growth momentum for technology innovation may have been the major challenge that the agriculture sectors in these three countries faced.

Unlike Bangladesh, India, and Pakistan, changes of agricultural TFP in Afghanistan and Iran fluctuated over time and were dominated by scale efficiency decline. Moreover, the growth patterns of agricultural TFP in Nepal and Sri Lanka were also not stable but showed some similarities. Both countries experienced technical progress at the beginning; however, the backward technology and reduced technical efficiency dragged down agricultural productivity from 2012. Moreover, Bhutan was the only south Asian country where agricultural TFP deteriorated every year. The technical change and technical efficiency change both declined each year, which had a negative impact on the agricultural productivity of Bhutan. 


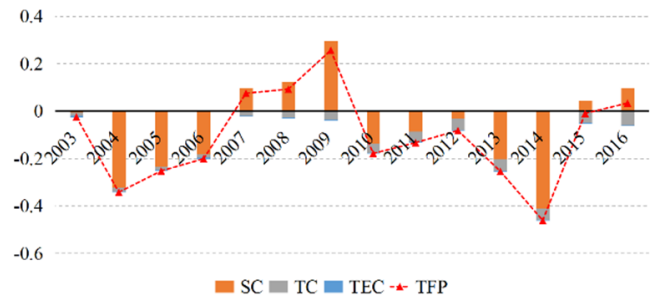

(a) Afghanistan

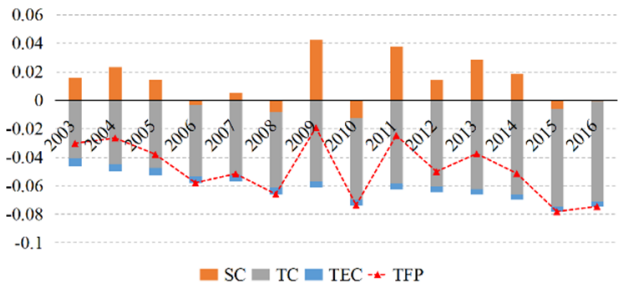

(c) Bhutan

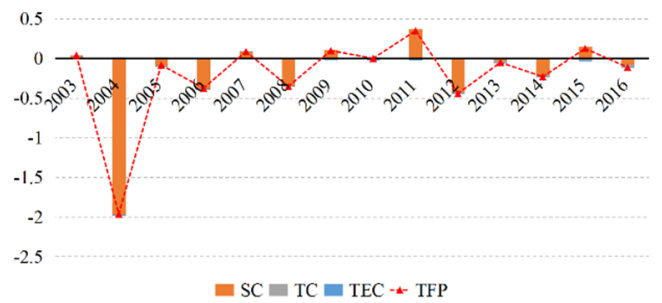

(e) Iran

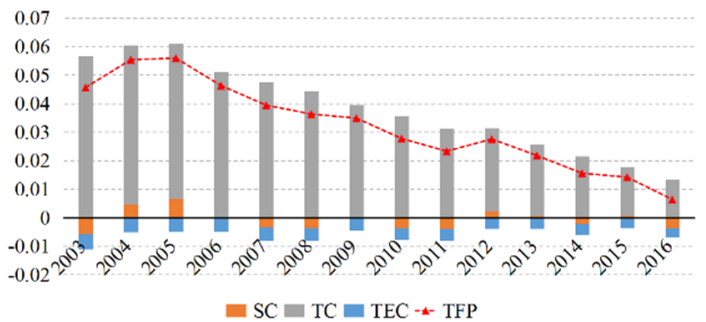

(g) Pakistan

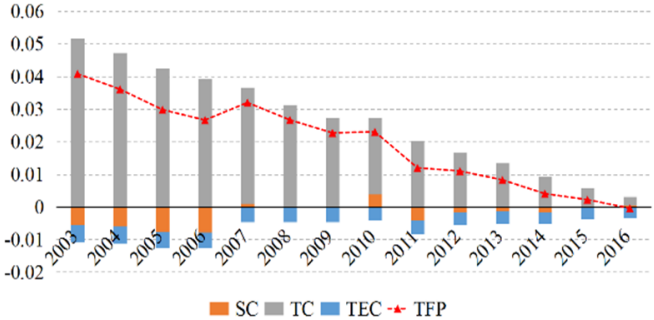

(b) Bangladesh

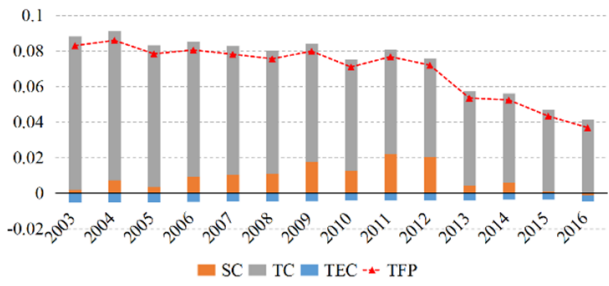

(d) India

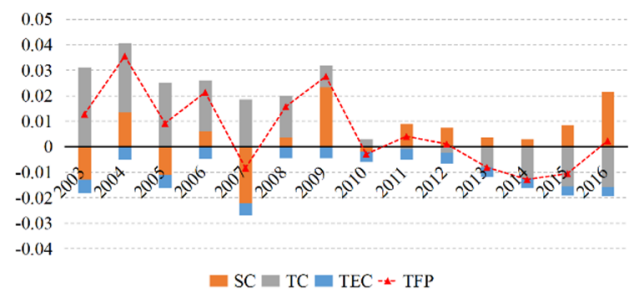

(f) Nepal

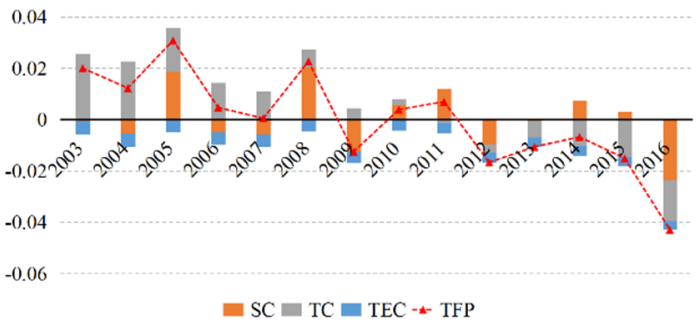

(h) Sri Lanka

Figure 1. Changes in agricultural total factor productivity (TFP) and its components in south Asia (SC: scale change; TC: technical change; TEC: technical efficiency change).

There were also several different growth patterns of agricultural productivity in southeast Asia (see Figure 2). First, the growth of agricultural TFP tended to slow down in Indonesia, Myanmar, the Philippines, Thailand, and Vietnam. India exhibited the best practices regarding agricultural production in the southeast Asian region; the continuous technical progress was a great help to its sustainable agricultural development. The slowdown trends of agricultural productivity growth in Myanmar, the Philippines, Thailand, and Vietnam were more obvious over time. The agricultural TFP of Myanmar and Thailand started to decline from 2011, while the growth rate of agricultural TFP in the Philippines and Vietnam also turned negative in 2016. The persistent slowdown of technical progress was the common factor driving the deterioration of agricultural TFP in these countries. 


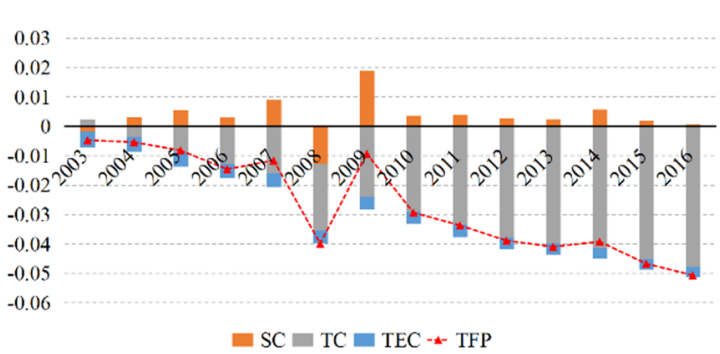

(a) Cambodia

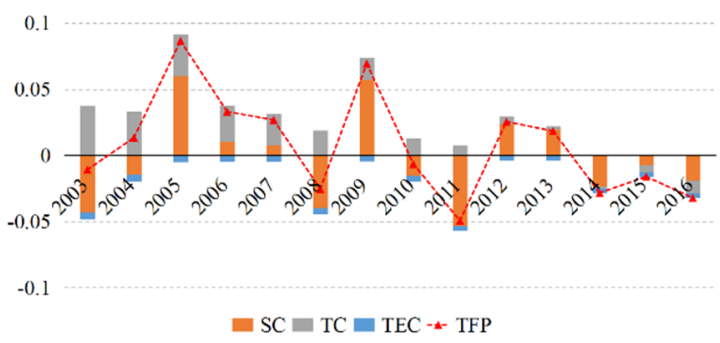

(c) Malaysia

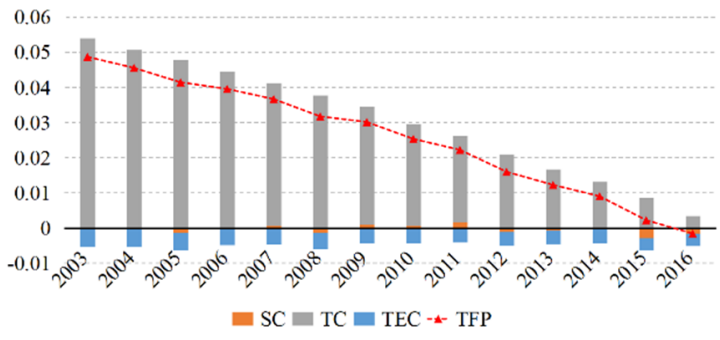

(e) Philippines

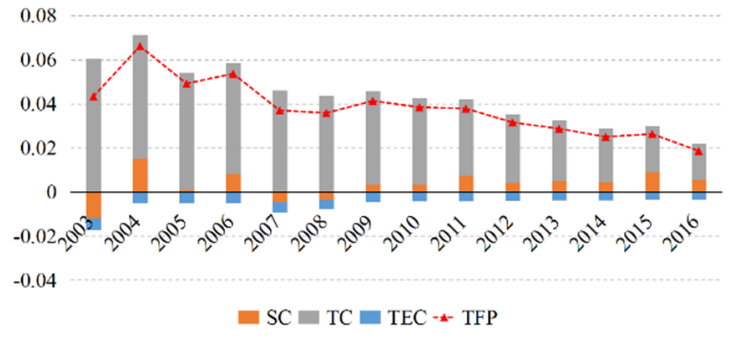

(b) Indonesia

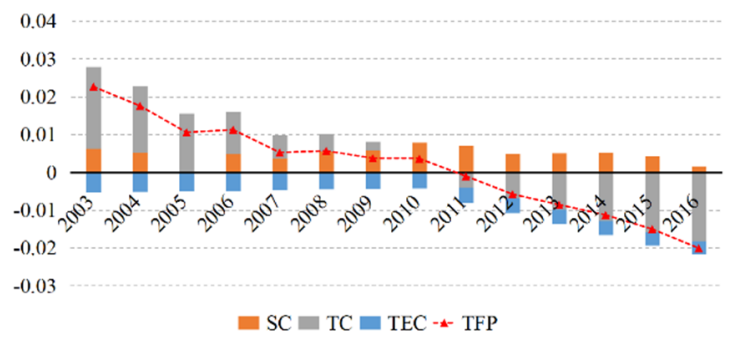

(d) Myanmar

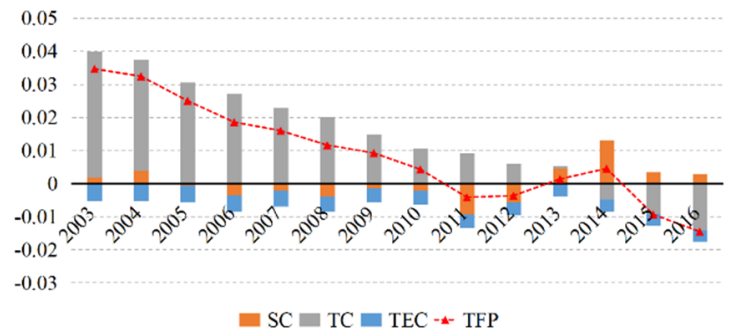

(f) Thailand

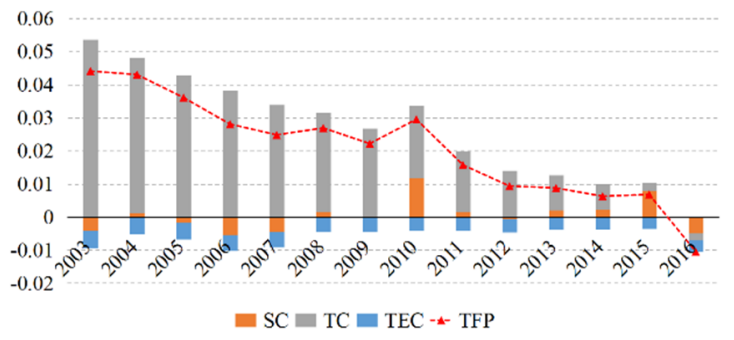

(g) Vietnam

Figure 2. Changes of agricultural total factor productivity (TFP) and its components in Southeast Asia (SC: Scale Change; TC: Technical change; TEC: Technical efficiency change).

Unlike the other southeast Asian countries, the agricultural TFP changes in Malaysia fluctuated, and this was mainly affected by scale change. A possible reason is that agriculture in Malaysia is still dominated by smallholders with an ageing farmer population, thereby causing diseconomies of scale in agricultural production [54]. Consolidating efficient and professional management of small farms is crucial for Malaysia to promote scale benefits in agricultural production. Like Bhutan, Cambodia was the only southeast Asian country that experienced a continuous deterioration of agricultural TFP due 
to technical regression and efficiency decline. The technical regression of agriculture in Cambodia worsened during the sample period.

\subsection{Factors Explaining Agricultural TFP Changes}

In this subsection, we applied the FD-GMM estimator to dynamic data models to explain the determinants of agricultural TFP changes in south and southeast Asian countries. The estimated results of the SYS-GMM estimator are also provided as a robustness check. The presence of endogeneity could result in inconsistent estimated results, but the problem can be addressed by instrumental variables [55,56]. In dynamic panel data models, the FD-GMM and SYS-GMM estimators can deal with the problem of endogeneity by using instrumental variables $[50,57]$. The estimated parameters of the dynamic FD-GMM estimator and the results of model diagnostics are presented in Table 7. The statistics from Sargan's test rejected the null hypothesis that the over-identifying restrictions were valid, suggesting that the instrument variables as a group were exogenous, and that the choice of instruments was reasonable in our model. Meanwhile, the results of Arellano-Bond tests for zero autocorrelation in the first-difference disturbances showed that the disturbances were not serially correlated. The null hypothesis of the Wald test is that "the coefficients on the explanatory variables are jointly zero", which was strongly rejected, implying that the inclusion of explanatory variables was reasonable.

Table 7. Dynamic first-difference generalized method of moments (FD-GMM) and system generalized method of moments (SYS-GMM) estimators for the determinants of TFP changes.

\begin{tabular}{ccccc}
\hline Models & \multicolumn{2}{c}{ FD-GMM } & \multicolumn{2}{c}{ SYS-GMM } \\
\hline Variables & Coef. & Std.Error & Coef. & Std.Error \\
\hline Lagged change in TFP & -0.0598 & 0.0397 & $-0.0753^{* *}$ & 0.0298 \\
GDP per capita & $-0.1879^{* * *}$ & 0.0265 & $-0.1690^{* * *}$ & 0.0315 \\
Human capital & $0.0386^{*}$ & 0.0216 & $0.0626^{* * *}$ & 0.0190 \\
Agricultural export & -0.0002 & 0.0060 & 0.0113 & 0.0073 \\
Agricultural import & $-0.0137^{* * *}$ & 0.0012 & $-0.0104^{* * *}$ & 0.0019 \\
Urbanization & $0.0246^{* * *}$ & 0.0059 & 0.0012 & 0.0041 \\
Development flow & $0.0037^{* * *}$ & 0.0002 & $0.0038^{* * *}$ & 0.0002 \\
Time dummy 1(=1 from 2003 to 2007) & $0.0387^{* * *}$ & 0.0083 & $-0.0281^{* *}$ & 0.0108 \\
Time dummy 2(=1 from 2008 to 2012) & $0.0480^{* * *}$ & 0.0085 & 0.0106 & $0.0064^{*}$ \\
Constant & $0.4183^{*}$ & 0.2523 & $0.9592^{* * *}$ & 0.1947 \\
\hline Wald test (chi ${ }^{*}$ ) & Model Diagnostics & & \\
Wald test $(p$ value) & $50,406.38$ & & 8087.92 & \\
Sargan's test (chi $\left.{ }^{2}\right)$ & 0.0000 & & 0.0000 & \\
Sargan's test $(p$ value) & 12.204 & & 10.612 & \\
Arellano-Bond test for AR (1) & 1.0000 & & 1.0000 & \\
(z-statistic) & & & & \\
( $p$ value) & -1.0835 & & 0.1 .1180 & \\
(z-statistic) & 0.2786 & & 0.9846 & \\
( $p$ value) & 0.9859 & & 0.3248 & \\
Arellano-Bond fest for AR (2) & 0.3242 & & & \\
\hline
\end{tabular}

Note: Significance at the $0.01,0.05$, and 0.10 levels are indicated by ${ }^{* * *}, * *, *$, respectively; AR (1): first-order autocorrelation; AR (2): second-order autocorrelation.

The level of economic development, measured by GDP per capita, was significant and negatively correlated with agricultural TFP change, indicating that higher income levels were associated with a slower growth in agricultural TFP. Many south and southeast Asian countries were in a period of economic transformation with increasing shares of industry and services. The share of agriculture in total GDP was declining, but employment in agriculture still accounted for a large proportion of employment in these countries. This phenomenon implies that the agricultural productivity 
of these countries was not keeping pace with economic development. Consequently, south and southeast Asian countries experienced slower agricultural productivity growth despite continuous economic development.

Human capital positively contributed to the growth of agricultural productivity. Human capital can directly increase a worker's productivity, thus contributing to improvements in agricultural TFP. This result is consistent with the findings by Lanzona [58], Anik et al. [6], and Zakaria et al. [36], who also focused on the agricultural productivity of south Asian or southeast Asian countries and concluded that agricultural productivity increased with an increase in human capital. However, some studies found a negative role of human capital on agricultural productivity. For example, Rahman and Salim [59] mentioned that human capital significantly contributed to technical progress but had a negative impact on technical efficiency, scale efficiency, and TFP growth in Bangladesh.

Regarding agricultural trade, we found a negative relationship between agricultural import and TFP changes. In theory, developing countries can learn advanced technologies and management experience through importing goods and services from developed countries, which is the so-called demonstration effect, thereby contributing to the improvement of productivity. Nevertheless, there may also be a loss of human and physical capital for local firms due to international competition, leading to the backwardness of agricultural productivity [39]. The negative value of agricultural import in this study indicated that domestic agricultural products faced fierce competition from imported products but without the obvious benefits of the demonstration effect. On the other hand, agricultural export can help to achieve economies of scale by expanding markets overseas. Exporters also can improve their technological innovation capacities through experience from international competition [31]. However, our result shows no significant effect of agricultural export on agricultural TFP, though it may exist theoretically.

Urbanization was positively associated with changes in agricultural productivity. With limited land resources, urbanization contributes to the transformation of the labor force from the countryside to urban areas, thereby promoting the rational reallocation of agricultural labor input. In addition, farmers in suburban areas can take advantage of the proximity to urban centers to reduce costs. Therefore, urbanization is helpful to improve efficiency and accelerate productivity growth. The positive impact of urbanization on agricultural productivity is also evident in work by Kumar et al. [25] and Oueslati and $\mathrm{Wu}[60]$. However, it has been argued that urbanization may have adverse effects on agricultural productivity, because urban land expansion will lead to cropland loss, which has become a major concern in terms of food production and supply [61]. The key issue is whether the growing demand for food and more convenient access to the market due to urbanization can maintain the sustainable development of agriculture given the decline of agricultural land [62].

The development flow to agriculture positively contributed to the growth in agricultural TFP. Therefore, the development assistance to agricultural sectors was effective in improving the agricultural productivity of south and southeast Asian countries. Ssozi et al. [41] also found a positive relationship between development assistance and agricultural productivity. The two time dummy variables were both significant and positive, which indicated that the earlier periods experienced a higher growth rate of agricultural productivity. This result reveals that the growth rate of agricultural TFP in south and southeast Asian countries declined significantly. However, the lagged changes in TFP showed no significant association with TFP changes in current periods.

The signs and significance level for the coefficients of most explanatory variables in the SYS-GMM model were consistent with the results in the FD-GMM model. Concretely speaking, human capital and development flow to agriculture were confirmed to have a significant positive influence on changes in agricultural TFP, whereas GDP per capita and agricultural import still showed significant negative signs in the SYS-GMM model. The results of a robustness test further verified the credibility of our findings for factors affecting changes in agricultural productivity in south and southeast Asia. 


\section{Conclusions and Policy Recommendations}

This study examined the agricultural productivity growth of 15 south and southeast Asian countries from 2002 to 2016 using a stochastic frontier model in order to assess the sustainability of their agricultural sectors. Through the decomposition of TFP, we identified scale change, technical change, and technical efficiency change as the components of agricultural productivity growth. Subsequently, the influencing factors on agricultural productivity change in south and southeast Asia were investigated using dynamic panel data models. The main conclusions of this study can be drawn as follows:

South and southeast Asian countries overall witnessed declined agricultural productivity during the period 2002-2016, reflecting the unsustainable development route of their agricultural sectors. Technical progress made major contributions to agricultural productivity growth. As mentioned by Huang and Chien [63], the lack of environmental and social sustainability is a principal problem existing in the agriculture sector, while innovation is the key to solving this problem. On the contrary, scale and technical efficiency change both resulted in a decline in agriculture TFP. At the regional level, south Asia experienced agricultural productivity deterioration overall, although there was obvious technical progress in some south Asian countries during the sample period, such as India, Pakistan, and Bangladesh. On the contrary, there were improvements in agricultural productivity in southeast Asia over time, owing to the progress of technology. In comparison with south Asian countries, southeast Asian countries have achieved more stable and sustained growth in agriculture productivity.

Agricultural productivity in the countries of south and southeast Asia faced different growth patterns. In the first place, many south and southeast Asian countries, including Bangladesh, India, Pakistan, and Nepal in south Asia, as well as Indonesia, the Philippines, Vietnam, Thailand, and Malaysia in southeast Asia, on average experienced improvements in agricultural productivity mainly powered by technical progress. Next, Myanmar also witnessed a slight increase in agricultural productivity; however, the improvement was largely the result of gains from scale efficiency. On the contrary, Afghanistan and Iran experienced an obvious productivity deterioration because of the loss of scale efficiency, while weakened technology was the major cause for productivity decline in Bhutan and Cambodia.

The changes in agricultural TFP showed several dynamic characteristics. First, the growth speed of agricultural TFP slowed down together with technical progress in many countries, such as Bangladesh, India, Nepal, Pakistan, and Sri Lanka in south Asia, as well as Indonesia, Myanmar, the Philippines, Thailand, and Vietnam in southeast Asia. Among them, the agricultural TFP of Nepal, Sri Lanka, Myanmar, the Philippines, Thailand, and Vietnam gradually changed from an increase to a decline. Second, agricultural productivity in Bhutan and Cambodia kept falling every year because of the continued backwardness of technology. Third, changes in agricultural TFP in Afghanistan and Iran had obvious fluctuations over time due to unstable scale changes. Therefore, diseconomies of scale may be one of the major challenges for the sustained development of agriculture in Afghanistan and Iran.

Furthermore, our results indicate that human capital, urbanization, and development flow to agriculture are crucial factors that contributed significantly to the agricultural productivity growth of south and southeast Asian countries. On the contrary, income level and agricultural import were found to be negatively associated with agricultural productivity growth. In addition, we found no positive relationship between the lagged level and current level of TFP changes, implying that agriculture development in south Asia and southeast Asia overall has not been directed toward a sustainable path.

Based on the above conclusions, the following policy recommendations are proposed to promote productivity growth and the sustainable development of agriculture sectors in south and southeast Asia. First, south and southeast Asian countries should focus on technological innovation to increase productivity. Second, major frontier countries in the two regions, such as India and Indonesia, should take the lead on regional agricultural development and focus on enhancing cooperation with neighboring countries in terms of agricultural science and frontier technologies. Third, countries such as Afghanistan and Iran, which might face challenges from diseconomies of scale, should attach 
importance to the rational allocation of agricultural inputs, especially for the reasonable investment of agricultural capital, thereby avoiding over-investment and adverse impacts from diseconomies of scale. Fourth, governments should increase investment in human capital to promote sustainable productivity improvement in agriculture. Besides, making full use of financial assistance and development flow to agriculture may also be an effective measure to increase agricultural productivity and sustainability in south and southeast Asian countries.

This study renews the relevant research on agricultural productivity analysis but makes up for the inadequacy of related studies focusing on south and southeast Asian regions and provides a clear map of agricultural productivity growth and its determinants in major south and southeast Asian countries. Rather than the non-parametric methods that are frequently employed by previous studies, the application of SFA confers the advantage of taking into account and controlling for random errors and statistical noise when estimating productivity and efficiency, thereby providing new findings for the related studies conducted on the basis of parametric estimation methods. Furthermore, the findings of this study may be a useful reference from which policymakers can form targeted policies and strategies to maintain the sustained growth of agriculture, and the agricultural sectors and farmers of different countries can enhance cooperation and accelerate technological progress, thereby promoting agricultural productivity growth in south and southeast Asian regions under the goals of sustainability.

One limitation of this study is that it only considers the key socio-economic factors in explaining agricultural TFP change. However, agricultural production is also influenced by environmental conditions and/or climate change. Therefore, relevant environmental and climate variables may be included in future research to identify the trade-off relationships between agricultural development and environmental sustainability.

Author Contributions: Conceptualization, J.L., M.W., and S.R.; Data curation, M.W.; Methodology, J.L., M.W., and S.S.; Software, M.W.; Supervision, J.L. and S.S.; Writing — original draft, M.W.; Writing-review and editing, J.L., M.W., L.Y., and S.R. All authors have read and agreed to the published version of the manuscript.

Funding: This research received no external funding.

Acknowledgments: This work has been supported by the Faculty of Economics and the Centre of Excellence in Econometrics at Chiang Mai University, as well as the Faculty of Economics at Shandong University of Finance and Economics under research grant 19BJCJ46.

Conflicts of Interest: The authors declare no conflict of interest.

\section{References}

1. Kopittke, P.M.; Menzies, N.W.; Wang, P.; McKenna, B.A.; Lombi, E. Soil and the intensification of agriculture for global food security. Environ. Int. 2019, 132, 105078. [CrossRef] [PubMed]

2. Masud, M.M.; Aldakhil, A.M.; Nassani, A.A.; Azam, M.N. Community-based ecotourism management for sustainable development of marine protected areas in Malaysia. Ocean Coast. Manag. 2017, 136, 104-112. [CrossRef]

3. Pretty, J. Agricultural sustainability: Concepts, principles and evidence. Philos. Trans. R. Soc. B Biol. Sci. 2008, 363, 447-465. [CrossRef] [PubMed]

4. Coomes, O.T.; Barham, B.L.; MacDonald, G.K.; Ramankutty, N.; Chavas, J.-P. Leveraging total factor productivity growth for sustainable and resilient farming. Nat. Sustain. 2019, 2, 22-28. [CrossRef]

5. Mozumdar, L. Agricultural productivity and food security in the developing world. Bangladesh J. Agric. Econ. 2012, 35, 53-69.

6. Anik, A.R.; Rahman, S.; Sarker, J.R. Agricultural productivity growth and the role of capital in South Asia (1980-2013). Sustainability 2017, 9, 470. [CrossRef]

7. Briones, R.M. Transformation and Diversification of the Rural Economy in Asia; The IFAD Research Series; Philippine Institute for Development Studies: Rome, Italy, 2017.

8. Kim, J.; Park, H.; Chun, J.A.; Li, S. Adaptation strategies under climate change for sustainable agricultural productivity in Cambodia. Sustainability 2018, 10, 4537. [CrossRef] 
9. Szudy, M. Agriculture in the Southeast Asian countries under globalization. Studia Ekonomiczne 2015, 218, 146-156.

10. Intal, P.S., Jr. The Economic Transformation of the ASEAN Region in Comparative Perspective. In ASEAN Member States: Transformation and Integration; Economic Research Institute for ASEAN and East Asia: Jakarta, Indonesia, 2017; p. 1.

11. Atapattu, S.S.; Kodituwakku, D.C. Agriculture in South Asia and its implications on downstream health and sustainability: A review. Agric. Water Manag. 2009, 96, 361-373. [CrossRef]

12. Erbaugh, J.; Bierbaum, R.; Castilleja, G.; da Fonseca, G.A.; Hansen, S.C.B. Toward sustainable agriculture in the tropics. World Dev. 2019, 121, 158-162. [CrossRef]

13. Gillespie, S.; Poole, N.; van den Bold, M.; Bhavani, R.; Dangour, A.D.; Shetty, P. Leveraging agriculture for nutrition in South Asia: What do we know, and what have we learned? Food Policy 2019, 82, 3-12. [CrossRef]

14. Lynam, J.K.; Herdt, R.W. Sense and sustainability: Sustainability as an objective in international agricultural research. Agric. Econ. 1989, 3, 381-398. [CrossRef]

15. Sujan, P.; Akira, K.; Hironori, Y. Sources of Agricultural Productivity Growth in South and Southeast Asia. Trends Agric. Econ. 2011, 4, 18-29.

16. Van Beveren, I. Total factor productivity estimation: A practical review. J. Econ. Surv. 2012, 26, 98-128. [CrossRef]

17. Kumbhakar, S.C.; Lovell, C.K. Stochastic Frontier Analysis; Cambridge University Press: Cambridge, UK, 2003.

18. Adetutu, M.O.; Ajayi, V. The impact of domestic and foreign R\&D on agricultural productivity in sub-Saharan Africa. World Dev. 2020, 125, 104690.

19. Nakano, Y.; Magezi, E.F. The impact of microcredit on agricultural technology adoption and productivity: Evidence from randomized control trial in Tanzania. World Dev. 2020, 133, 104997. [CrossRef]

20. Gottlieb, C.; Grobovšek, J. Communal land and agricultural productivity. J. Dev. Econ. 2019, 138, $135-152$. [CrossRef]

21. Jin, G.; Li, Z.; Deng, X.; Yang, J.; Chen, D.; Li, W. An analysis of spatiotemporal patterns in Chinese agricultural productivity between 2004 and 2014. Ecol. Indic. 2019, 105, 591-600. [CrossRef]

22. Wang, S.L.; Huang, J.; Wang, X.; Tuan, F. Are China's regional agricultural productivities converging: How and why? Food Policy 2019, 86, 101727. [CrossRef]

23. Gong, B. Agricultural productivity convergence in China. China Econ. Rev. 2020, 60, 101423. [CrossRef]

24. Rahman, S.; Anik, A.R. Productivity and efficiency impact of climate change and agroecology on Bangladesh agriculture. Land Use Policy 2020, 94, 104507. [CrossRef]

25. Kumar, P.; Kumar, A.; Mittal, S. Total factor productivity of crop sector in the Indo-Gangetic Plain of India: Sustainability issues revisited. Indian Econ. Rev. 2004, 39, 169-201.

26. Emerick, K. Agricultural productivity and the sectoral reallocation of labor in rural India. J. Dev. Econ. 2018, 135, 488-503. [CrossRef]

27. Tripathi, A. Total factor productivity growth in Indian agriculture. J. Glob. Econ. 2010, 6, 286-298.

28. Tripathi, A.; Prasad, A. Agricultural development in India since independence: A study on progress, performance, and determinants. J. Emerg. Knowl. Emerg. Mark. 2010, 1, 8. [CrossRef]

29. Kapri, K.; Ghimire, S. Migration, remittance, and agricultural productivity: Evidence from the Nepal Living Standard Survey. World Dev. Perspect. 2020, 100198. [CrossRef]

30. Yamamoto, Y.; Shigetomi, Y.; Ishimura, Y.; Hattori, M. Forest change and agricultural productivity: Evidence from Indonesia. World Dev. 2019, 114, 196-207. [CrossRef]

31. Giang, M.H.; Xuan, T.D.; Trung, B.H.; Que, M.T. Total Factor Productivity of Agricultural Firms in Vietnam and Its Relevant Determinants. Economies 2019, 7, 4. [CrossRef]

32. Ayerst, S.; Brandt, L.; Restuccia, D. Market constraints, misallocation, and productivity in Vietnam agriculture. Food Policy 2020, 101840. [CrossRef]

33. Le, K. Land use restrictions, misallocation in agriculture, and aggregate productivity in Vietnam. J. Dev. Econ. 2020, 102465. [CrossRef]

34. Enu, P.; Attah-Obeng, P. Which macro factors influence agricultural production in Ghana? Acad. Res. Int. 2013, 4, 333.

35. Jiang, L.; Li, Z. Urbanization and the change of fertilizer use intensity for agricultural production in Henan Province. Sustainability 2016, 8, 186. [CrossRef] 
36. Zakaria, M.; Jun, W.; Khan, M.F. Impact of financial development on agricultural productivity in South Asia. Agric. Econ. 2019, 65, 232-239. [CrossRef]

37. Ndour, C.T. Effects of human capital on agricultural productivity in Senegal. World Sci. News 2017, 34-43.

38. Gopinath, M.; Kennedy, P.L. Agricultural trade and productivity growth: A state-level analysis. Am. J. Agric. Econ. 2000, 82, 1213-1218. [CrossRef]

39. Fleming, D.A.; Abler, D.G. Does agricultural trade affect productivity? Evidence from Chilean farms. Food Policy 2013, 41, 11-17. [CrossRef]

40. Pavcnik, N. Trade liberalization, exit, and productivity improvements: Evidence from Chilean plants. Rev. Econ. Stud. 2002, 69, 245-276. [CrossRef]

41. Ssozi, J.; Asongu, S.; Amavilah, V.H. The effectiveness of development aid for agriculture in Sub-Saharan Africa. J. Econ. Stud. 2019. [CrossRef]

42. Rezitis, A.N. Agricultural productivity and convergence: Europe and the United States. Appl. Econ. 2010, 42, 1029-1044. [CrossRef]

43. Li, N.; Jiang, Y.; Mu, H.; Yu, Z. Efficiency evaluation and improvement potential for the Chinese agricultural sector at the provincial level based on data envelopment analysis (DEA). Energy Econ. 2018, 164, 1145-1160. [CrossRef]

44. Chou, Y.-C.; Shao, B.B.; Lin, W.T. Performance evaluation of production of IT capital goods across OECD countries: A stochastic frontier approach to Malmquist index. Decis. Support Syst. 2012, 54, 173-184. [CrossRef]

45. Liu, J.; Wang, M.; Ma, J.; Rahman, S.; Sriboonchitta, S. A Simultaneous Stochastic Frontier Model with Dependent Error Components and Dependent Composite Errors: An Application to Chinese Banking Industry. Mathematics 2020, 8, 238. [CrossRef]

46. Benedetti, I.; Branca, G.; Zucaro, R. Evaluating input use efficiency in agriculture through a stochastic frontier production: An application on a case study in Apulia (Italy). J. Clean. Prod. 2019, 236, 117609. [CrossRef]

47. Battese, G.E.; Coelli, T.J. Frontier production functions, technical efficiency and panel data: With application to paddy farmers in India. J. Product. Anal. 1992, 3, 153-169. [CrossRef]

48. Kim, S.; Han, G. A decomposition of total factor productivity growth in Korean manufacturing industries: A stochastic frontier approach. J. Product. Anal. 2001, 16, 269-281. [CrossRef]

49. Arellano, M.; Bond, S. Some tests of specification for panel data: Monte Carlo evidence and an application to employment equations. Rev. Econ. Stud. 1991, 58, 277-297. [CrossRef]

50. Carstensen, K.; Toubal, F. Foreign direct investment in Central and Eastern European countries: A dynamic panel analysis. J. Comp. Econ. 2004, 32, 3-22. [CrossRef]

51. Blundell, R.; Bond, S. Initial conditions and moment restrictions in dynamic panel data models. J. Econom. 1998, 87, 115-143. [CrossRef]

52. Fuglie, K.O. Is agricultural productivity slowing? Glob. Food Secur. 2018, 17, 73-83. [CrossRef]

53. Minten, B.; Dukpa, C. Technology Adoption, Agricultural Productivity, and Road Infrastructure in Bhutan; Policy and Planning Division, Ministry of Agriculture and Forests: Thimphu, Bhutan, 2010.

54. Bakar, B.B. The Malaysian agricultural industry in the new millennium: Issues and challenges. In Proceedings of the International Conference on Malaysia: Malaysia in Global Perspective, Cairo, Egypt, 27-28 September 2009; pp. 337-356.

55. Bascle, G. Controlling for endogeneity with instrumental variables in strategic management research. Strateg. Organ. 2008, 6, 285-327. [CrossRef]

56. Chen, H.-C.; Chang, K.-L.; Yu, S.-T. Application of the Tobit model with autoregressive conditional heteroscedasticity for foreign exchange market interventions. Jpn. World Econ. 2012, 24, 274-282. [CrossRef]

57. Bond, S.R. Dynamic panel data models: A guide to micro data methods and practice. Port. Econ. J. 2002, 1, 141-162. [CrossRef]

58. Lanzona, L.A., Jr. Human Capital and Agricultural Productivity: The Case of the Philippines. In Product. Growth Philipp. Agric.; Southeast Asian Regional Center for Graduate Study and Research in Agriculture (SEARCA): Los Baños, Philippines, 2013; Volume 10.

59. Rahman, S.; Salim, R. Six decades of total factor productivity change and sources of growth in Bangladesh agriculture (1948-2008). J. Agric. Econ. 2013, 64, 275-294. [CrossRef]

60. Oueslati, W.; Salanié, J.; Wu, J. Urbanization and agricultural productivity: Some lessons from European cities. J. Econ. Geogr. 2019, 19, 225-249. [CrossRef] 
61. D'Amour, C.B.; Reitsma, F.; Baiocchi, G.; Barthel, S.; Güneralp, B.; Erb, K.-H.; Haberl, H.; Creutzig, F.; Seto, K.C. Future urban land expansion and implications for global croplands. Proc. Natl. Acad. Sci. USA 2017, 114, 8939-8944. [CrossRef] [PubMed]

62. Satterthwaite, D.; McGranahan, G.; Tacoli, C. Urbanization and its implications for food and farming. Philos. Trans. R. Soc. B Biol. Sci. 2010, 365, 2809-2820. [CrossRef]

63. Huang, W.-T.; Chien, C.-Y. Patterns and Factors of Farming Innovation in Taiwan. J. Agric. Sci. 2013, 5, 269. [CrossRef]

(C) 2020 by the authors. Licensee MDPI, Basel, Switzerland. This article is an open access article distributed under the terms and conditions of the Creative Commons Attribution (CC BY) license (http://creativecommons.org/licenses/by/4.0/). 